\title{
PROBLEMS AND PROSPECTS OF RUSSIA'S MIGRATION POLICY
}

\author{
(C) Lira K. Gurieva
}

\author{
The Federal State-Funded Educational Institution of Higher Education Financial University \\ under the Government of the Russian Federation, Republic of North Ossetia-Alania, \\ Vladikavkaz, Russian Federation \\ 443879@mail.ru
}

Migration processes play an important role for the socio-economic and demographic development of countries and regions. At the same time, the unresolved nature of migration issues in Russia is often a source of demographic tension, which requires the intensification of international cooperation of the country and the implementation of an effective policy to solve emerging problems in the field of migration. The dialectical challenge of modern Russia is the fact that, on the one hand, over the last decade Russia's migration attractiveness has grown twice, and on the other hand, the outflow of migrants from Russia has increased 11 fold. This, in many respects, is the result of a controversial, inconsistent migration policy, within the framework of which Russia's interest in attracting permanent migrants in general and "compatriots" in particular is declared verbally, and in fact, there is a rapidly growing outflow of the Russian population to the countries of near and far abroad mainly due to tensions in the labor market, difficulties in gainful employment in Russia. Such an approach has a negative "demonstration effect" for potential migrants and directly contradicts the strategic goal of stimulating the influx of migrants in order to mitigate the last two decades of the demographic crisis in Russia. The most painful for the Russian economy is the high educational and qualification level of citizens leaving Russia, which, compared with the low education of a significant part of labor migrants arriving in Russia in search of work, which leads to a deterioration in the quality of the labor force employed in the Russian labor market, and acts as an obstacle to the formation of an innovative type of development of the Russian economy.

Key words: migration, migration attractiveness, migration outflow, migration policy.

\section{[Л.К. Гуриева Проблемы и перспективы миграционной политики России]}

Миграционные процессы играют важную роль для социально-экономического и демографического развития стран и регионов. Вместе с тем, неразрешенность миграционных вопросов в России зачастую является источником демографической напряженности, что требует интенсификации международного сотрудничества страны и реализации эффективной политики для решения возникающих проблем в сфере миграции. Диалектическим вызовом современной России является 2-кратный рост за последнее десятилетие миграционной привлекательности России, с одной стороны, с другой же 11-кратное увеличение оттока мигрантов из России. Это, во многом, результат противоречивой, непоследовательной миграционной политики, в рамках которой на словах декларируется заинтересованность России в привлечении постоянных мигрантов в целом и «соотечественников» в частности, а на деле наблюдается бурно растущий отток населения России в страны ближнего и дальнего зарубежья преимущественно из-за напряженности на рынке труда, трудностей выгодного трудоустройства на территории России. Такой подход имеет негативный «демонстрационный эффект» для потенциальных переселенцев и вступает в прямое противоречие со стратегической целью стимулирования притока мигрантов для смягчения, продолжающегося последние два десятилетия демографического кризиса в России. Наиболее болезненным для экономики России является высокий образовательный и квалификационный уровень выезжающих из России граждан, что в сравнении с низкой образованностью значительной части трудовых мигрантов, прибывающих в Россию в поисках работы, что приводит к ухудшению качества задействованной на российском рынке труда рабочей силы, и выступает преградой на пути формирования инновационного типа развития российской экономики.

Ключевые слова: миграция, миграционная привлекательность, миграционный отток, миграционная политика.

Lira K. Gurieva - Ph.D. (Advanced Doctorate) in Economy, Professor, the Federal State-Funded Educational Institution of Higher Education Financial University under the Government of the Russian Federation, Republic of North Ossetia-Alania, Vladikavkaz, Russian Federation. 
Гуриева Лира Константиновна - доктор экономических наук, профрессор, Владикавказский фрилиал Финансового университета при Правительстве РФ, г. Владикавказ, Республика Северная ОсетияАлания, Российская Федерация.

Over the past three decades, migration has been one of the most strategically significant processes, along with the introduction of information and communication technologies. Important prerequisites for its development are the inequalities in the economic development of countries that have developed since the end of the $20^{\text {th }}$ century and are combined in the $21^{\text {st }}$ century with growing demographic inequality. The overabundance of the working-age population in economically less developed countries with a shortage of workers in the economies of developed countries is an objective prerequisite for forecasts of increased international migration in the first quarter - middle of the $21^{\text {st }}$ century.

Russia is among the countries experiencing a demographic crisis. So, according to available expert forecasts based on prevailing statistics and demographic behavior of the population in the country, Russian Federal State Statistics Service (Rosstat) made a forecast of changes in the population of Russia of working age until 2050 (Figure 1).

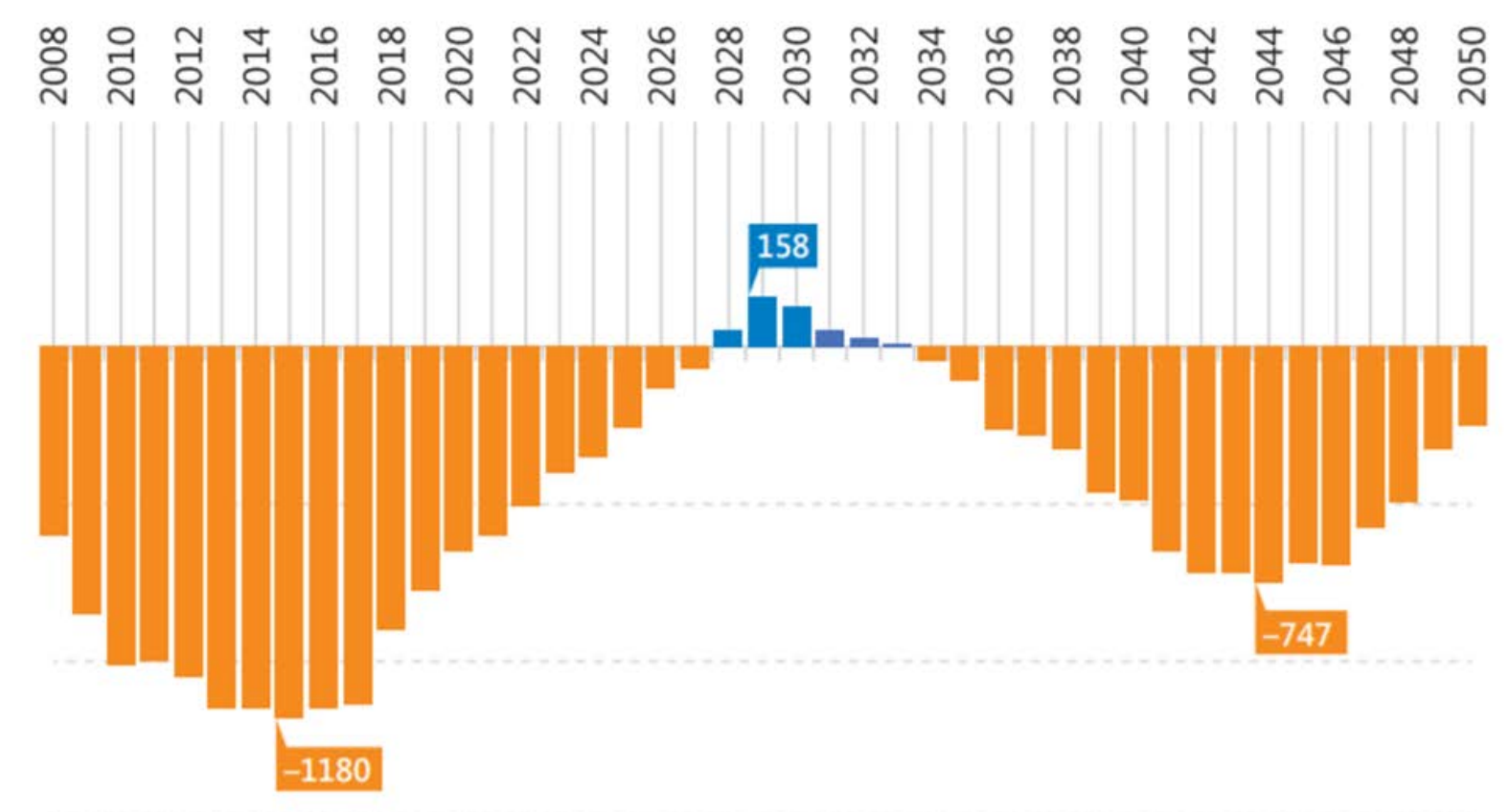

Figure 1. Change in the Russian population of working age (men - 16-59 years old, women 16-54 years old), 2008-2050, K people.

Source: Demographic Yearbook of Russia -2015. M.: Rosstat, 2015.

As shown in Fig. 1, the lowest point in making projections was adopted in 2015, when the reduction in the number of labour force population was more than 1.1 million people. And the most favorable forecast point will be reached in 2029 , when the forecast for the growth of the country's labour force corresponds to 158 thousand people.

To fill the shortage of personnel in the labour market, our country uses external migration, which covers the current deficit. As can be seen from Table 1, the number of migrants during the analyzed period increased from 281614 to 565685 people (an increase of 284071 people, an increase of 2.09 times). At the same time, 261,170 people arrived in Russia from the CIS (Commonwealth of Independent States) countries in 2008 and 510,994 people in 2018 (an increase of 249,824 people, an increase of 1.96 times in 2008- 
2018). From countries of the far abroad in $2008,20,444$ people arrived in our country, and in 2018 - 34,247 more people, or 54,691 people, which is 2.68 times more than 10 years ago.

However, these statistics cannot be considered in isolation from the analysis of the outflow of the labour force population from Russia.

An analysis of the data in Table 1 shows that 39,508 people left the Russian Federation in 2008, and in 2018 this flow increased 11.2 times to 440,831 people. At the same time, 25,542 people left for the CIS countries in 2008. And ten years later, 15 times more people left the country in the CIS countries - 381918 people. To foreign countries in the period 2008-2018 the outflow of the able-bodied population, as can be seen from the table, increased from 13,966 to 58,913 (an increase of 4.2 times).

Thus, in 2018, the net migration growth of the labour force is only 124854 people. This is 440831 less than arrivals.

Table 1. International migration of the Russian Federation in 2008-2019, people.

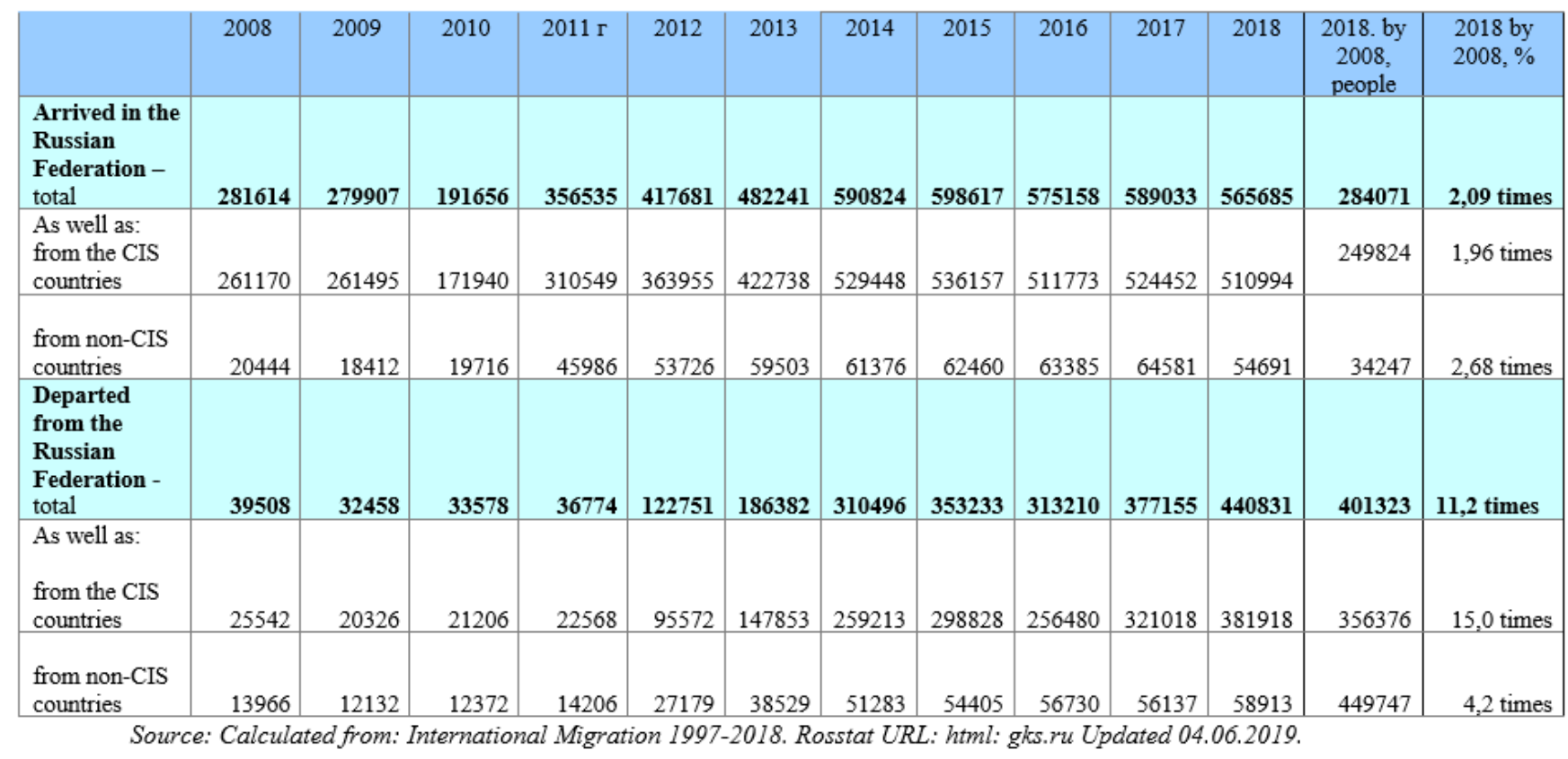

The reason for numerous omissions in the migration sphere was, among other things, the absence of a strategic orientation and conceptual coherence of management decisions in the migration sphere. As a result, unlike in previous historical periods, migration policy in post-Soviet Russia was not able to "integrate" into the national strategy and turn migration into an effective resource for the country's development.

The main problem of modern Russian migration policy is the lack of its conceptual clarity, the absence of clear guidelines for the future. In Russia, there was no justified, proceeding from considerations of state expediency and accepted at the official level idea of what the need of Russia for migrants is and what their role is in the future development of Russia.

The challenges of modern Russia is to reduce the migratory attractiveness of Russia for potential migrants. This is largely the result of a controversial, inconsistent migration policy, within the framework of which Russia's interest in attracting permanent migrants in general and "compatriots" in particular is declared verbally, but there are administrative barriers for newcomers to get legal status of immigrants, their employment and ways of resettlement them on the territory of Russia. There are still difficulties with housing rental 
due to the opacity of the housing market, and Russian labor market generally remains unattractive for educated youth. This approach has a negative "demonstration effect" for potential migrants and directly contradicts the strategic goal of stimulating the influx of migrants to mitigate the demographic crisis in Russia.

The report analyzes the main trends in the field of migration and formulates proposals on the migration policy of Russia.

Migration to a large part has an uncontrolled nature, despite the seemingly very active work of the authorized federal bodies. This leads to the formation of a significant segment of the unregistered employment of migrants, deforms the Russian labor market, and provokes the widespread exploitation of migrants up to forced and slave labor, as well as human trafficking. The lack of an effective mechanism for controlling migration to Russia worries society, makes migration an acute domestic political problem, and provokes the growth of radical nationalist sentiments.

The migration outflow of Russian citizens abroad is a serious demographic and economic challenge for Russia. The most painful for the Russian economy is the high educational and qualification level of leaving Russian citizens, which, in comparison with the low education of a significant part of labour migrants arriving in Russia in searching of work, leads to a deterioration in the quality of the labour force involved in the Russian labor market and acts as a brake on the formation of innovative type of development of the Russian economy.

The nature of internal Russian migration trends leads to an even more uneven, asymmetric distribution of the population over the territory of Russia. This unevenness has objective historical and climatic causes. However, it is intensified due to insufficient thoughtfulness of the Russian migration policy.

The main problem of modern Russian migration policy is the lack of its conceptual clarity, the lack of clear guidelines for the future. In Russia, there was no justified, proceeding from considerations of state expediency and accepted at the official level idea of what the need of Russia for migrants is and what their role is in the future development of Russia.

The strategic goals facing the Russian migration policy should be reviewed for all adopted normative acts and administrative decisions in this area. In the field of international migration, this is stimulating the influx of permanent migrants to stabilize the number of permanent population of Russia and temporary migrants to fill the deficit of the Russian labor market; in the field of internal migration, it is stimulating the influx of population into the strategically important eastern regions of the country. It is unacceptable when the adopted normative acts and law enforcement activities conflict with these goals.

It is important to maintain a visa-free regime of border crossing as a factor in the interconnectedness of the post-Soviet space. The CIS region is the intersection of the competing interests of a number of world and regional powers. The efforts of many players in the international arena are aimed at maximizing the political and economic distance from the former Soviet republics from each other. Russia, on the contrary, is interested in strengthening regional integration - both from an economic and geopolitical point of view. In such conditions, a visa-free regime for crossing state borders dividing the former republics of the USSR can be considered as a factor supporting the historical unity of the postSoviet space. Under this item, the Russian migration strategy intersects with the foreign policy strategy and may act as an additional factor in maintaining a stable political situation in the region.

The main goal in the field of labour migration is to create a working (not ignored by Russian employers and migrants) model of attracting foreign labor, which would follow from the real needs of the Russian labor market, without prejudice to the rights of Russian workers, and at the same time guarantee the rights of labor migrants. 
The policy on attracting labor migrants should be an additional, and not the main instrument for rectifying the situation on the labor market. In this regard, the urgent management task is to determine the real shortage of personnel in the Russian labor market, assess the possibilities of redistributing the available national labor resources and, based on this, the need to attract foreign labor. Such a task should be solved in conjunction with the implementation of the state socio-economic policy, employment policy, educational policy, regional development policy. The protection of the interests of national workers can be ensured not only by quantitative restrictions on foreign labor. Priority employment rights for Russian workers already guarantee their advantage in the labor market. Legally enforced implementation of the principle of equal pay for equal work for migrants and national workers is also in fact a mechanism for protecting the national labor market, as It does not allow migrants to be regarded as a source of cheap labour.

At the same time, the imposition of such artificial restrictions on the way of foreign workers to the Russian labour market, such as passing an exam on knowledge of the Russian language, history and legislation of Russia (which is certainly appropriate for foreign citizens applying for a residence permit and Russian citizenship) as conditions for obtaining permits documents on the right to work in Russia, can only divert the flows of labor migration into the sphere of shadow employment.

In order to provide the Russian labour market with foreign personnel of the necessary qualifications, it is necessary to solve the issue of vocational training of labor migrants at the state level. The relevance of this is evidenced by the high unmet demand for labour on the Russian labour market in the face of a significant influx of labour resources from abroad. Experience shows that vocational and language training of potential migrants in countries of origin often does not meet the requirements of Russian employers.

It is useful to provide the training of workers from among migrants in Russia on the basis of existing and the creation of new educational institutions of the secondary vocational education system. This would provide the necessary level of professional and at the same time language training. Training should be conducted on a credit basis, subject to the subsequent development of the loan amount in Russia. When in the future, citizens of the CIS countries who have received professional education in Russia return to their countries, their professional experience and qualifications will work for the development of these countries and thereby increase the sustainability of the economic development of the entire region.

One of the most important areas is the simplification of the order of academic mobility and study migration. Attracting foreign teachers and researchers can give a new impetus to the implementation of the idea of innovative development of the Russian economy. Attracting foreign students from the CIS countries to Russian universities can be considered as an investment in the human capital of partner countries of Russia, which has both an economic dimension (training for the development of the national economies of the CIS countries) and a political dimension (what is commonly called "soft power", which is able to strengthen Russia's political position in the region).

An important component of the state strategy should be internal migration policy. Economic measures that stimulate internal migration of the population - social benefits, soft loans for housing, tax benefits, including small business - are able to partially overcome the typical Russian mobility of the population and form the directions of migration that are desirable for the state.

It is necessary to codify migration legislation. Compliance with the adopted migration legislation (both by migrants and by executive bodies in the field of migration) should be subject to strict and effective control. Migration policies should be built using extended and updated databases. One of the mechanisms for implementing migration policy can be public-state partnership in this area. 
World Bank experts suggest that the Russian authorities move towards a more flexible regulation of migration flows - instead of restrictions, the Russian government should introduce measures to adapt the national labor market to growing competition for jobs. It is proposed to finance retraining and relocation of specialists through additional fees from migrants and their employers.

Russia, like many other countries of the Eastern European region, needs to move on to a more flexible policy of regulating labour migration, otherwise it will not be possible to use fully the potential of this resource for economic growth. Such advice is contained in a World Bank (WB) report on migration economies in Europe and Central Asia.

WB experts believe that labour mobility can soften demographic trends, ensure more substantial economic growth and reduce poverty in the region. If in rich European countries a high concentration of migrants often leads to increased unemployment and a deterioration in the quality of social services, then countries of Eastern Europe and Central Asia, on the contrary, may face a shortage of specialists. In Russia, according to the authors of the report, the share of migrants is now $5-10 \%$ of the population.

It should be noted that, as follows from the Concept of State Migration Policy for 2019-2025, adopted in autumn of 2018, the country needs a migration increase of 300 thousand people annually. At the same time, relevant experts doubt that the adoption of this concept can affect migration flows, since it does not contain fundamentally new approaches to their regulation. According to the calculations of the "Russian Demographic Sheet", the population of the Russian Federation by 2050 may be reduced by more than 15 million people (from the current 146 million), if there is an influx of migrants - only by 9 million.

The authors of the World Migration Report 2018 compiled by the International Migration Organization (IMO) talk about the importance of innovation in the field of migration management. In their opinion, the Russian approach to this area is too harsh, especially in terms of quotas for the permissible share of migrants in the sectors of the economy; the Russian government sets such quotas annually: for 2020, the largest share of hiring foreign citizens (80\%) is acceptable in the construction industry, the smallest - in the field of sports (25\%).

Instead of restrictions on the reception of migrants, the IMO report notes, Russia could focus on adapting its labour market to increased competition for jobs. For this, for example, it is possible to introduce retraining programs and changes in the youth education system so that young professionals do not compete with less qualified migrants. Successful professionals must be provided with subsidies for relocation or retraining in conjunction with the payment of temporary social benefits and unemployment insurance benefits. The necessary measures can be financed by replacing the quota system with tax measures and taxation of the labor market beneficiaries. Possible policies include introducing an additional tax, visa fee, or even a visa auction system. Such a paid system will allow employers to quickly adapt to changes in the labor market and mitigate the negative attitude towards immigrants.

\section{Лumepamypa}

1. Гуриева С.Д., Кинунен Т.А. Социально-психологические особенности миграционного поведения (на примере ингерманладских финнов) // Вопросы психологии. 2006. № 6. С. 97-104.

2. Демографический ежегодник России-2015. М.: Росстат, 2015. 
3. Конфисахор А. Г., Анисимова Т. В. Миграция как показатель социальной и психологической устойчивости людей (на примере Псковской области) // Психология в России: современное состояние. 2015.№ 8 (1). С.61-73.

4. Gurieva S.D., Kinunen T. (2014). Social-psychological Model of the «Migration Circle»: potential emigrants, migrants, remigrants // Open Journal of Social Sciences (JSS), 2014. 2 (11). pp.174-182.

5. Gurieva L. Conceptual Foundations of Social Responsibility of Corporate Structures: Historical Aspect // Научный альманах стран Причерноморья. 2018. № 4 (16). pр. 56-61.

6. Gurieva L.K. New Strategic Approach to the Innovative Development of Regions // Научный альманах стран Причерноморья. 2016. № 2 (6). pp. 1-4.

7. Gurieva L.K., Dzhioev A.V. Sustainable Development of The Russian Economy // Научный альманах стран Причерноморья. 2016 . № 2 (6). С. 5-8.

8. Gurieva S.D., Kostromina S. N., Tcvetkova L. A., Samuylova I. A., Konfisakhor A. G., Anisimova T. V. Migration as an indicator of people's social and psychological stability (as exemplified in the Pskov Region) // Psychology in Russia: State of the Art, 8 (1). 2015. Pp. 61-73.

9. Increasing the Development Impact of Migration through Finance and Technology: ADBI-ILO-OECD, 2018. URL: http://www.oecd.org/migration/labor-migration-in-asiaincreasing-the-development-impact-ofmigration-through-finance-and-technology9789264289642-en.htm

10. World Migration Report 2018. UK: IOM, 2018. URL: http://publications.iom.int/system/files/pdf/wmr_2018_en.pdf

\section{References}

1. Gurieva S.D., Kinunen T.A. Sotsialno-psikhologicheskiye osobennosti migratsi-onnogo povedeniya (na primere ingermanladskikh finnov). [Socio-psychological characteristics of migration behavior (on the example of Ingermanlad Finns)]. Voprosy psikhologii. 2006. No. 6. pp. 97-104 (in Russian).

2. Demograficheskiy yezhegodnik Rossii-2015. [Demographic Yearbook of Russia-2015]. Moscow: Rosstat, 2015 (in Russian).

3. Konfisakhor A. G., Anisimova T. V. Migratsiya kak pokazatel sotsial'noy i psikhologicheskoy ustoychivosti lyudey (na primere Pskovskoy oblasti). [Migration as an indicator of social and psychological stability of people (on the example of the Pskov region)].Psikhologiya v Rossii: sovremennoye sostoyaniye. 2015. No. 8 (1). pp. 61-73 (in Russian).

4. Gurieva S.D., Kinunen T. Social-psychological Model of the «Migration Circle»: potential emigrants, migrants, remigrants. Open Journal of Social Sciences (JSS), 2014. 2 (11). pp.174-182.

5. Gurieva L. Conceptual Foundations of Social Responsibility of Corporate Structures: Historical Aspect. Science Almanac of Black Sea Region Countries. 2018. No. 4 (16). pp. 56-61.

6. Gurieva L.K. New Strategic Approach to the Innovative Development of Regions. Science Almanac of Black Sea Region Countries. 2016. No. 2 (6). pp. 1-4.

7. Gurieva L.K., Dzhioev A.V. Sustainable Development of the Russian Economy. Science Almanac of Black Sea Region Countries. 2016. No. 2 (6). pp. 5-8. 
Научный альманах стран Причерноморья. 2019. Том 20. № 4

8. Gurieva S.D., Kostromina S. N., Tcvetkova L. A., Samuylova I. A., Konfisakhor A. G., Anisimova T. V. Migration as an indicator of people's social and psychological stability (as exemplified in the Pskov Region). Psychology in Russia: State of the Art, 8 (1). 2015. pp. 61-73.

9. Increasing the Development Impact of Migration through Finance and Technology: ADBI-ILO-OECD, 2018. Available at: http://www.oecd.org/migration/labor-migration-inasia-increasing-the-development-impact-ofmigration-through-finance-and-technology9789264289642-en.htm

10. World Migration Report 2018. UK: IOM, 2018.

Available at: http://publications.iom.int/system/files/pdf/wmr_2018_en.pdf

12 November, 2019 